\title{
An overview of the risk factors associated with multiple oral premalignant lesions with a case report of extensive field cancerization in a female patient
}

\author{
Gadiputi Sreedhar ${ }^{\text {a }}$, Masineni Narayanappa Sumalatha ${ }^{b}$, Deepika Shukla ${ }^{c}$
}

Background. Field cancerization is a well-known and well-documented process of malignant transformation first coined by Slaughter et al. in 1953. Tobacco chewing was associated with the greatest increase in the risk of multiple oral premalignant lesions and may be the major source of field cancerization of the oral cavity in the Indian population. The field cancerization will probably help clinicians in complementing evaluation of pathologic biopsy specimens.

Material and Methods. We present a case report of field cancerization in a 63-year-old Indian female. She presented with an intra-oral generalized hyperkeratotic verruciform type white lesions involving right and left buccal mucosa, lower labial mucosa, upper and lower vestibule, dorsal, ventral and right lateral border of the tongue, hard and soft palate. Microscopic examination revealed features of verrucous carcinoma in one area, squamous cell carcinoma in another and carcinoma in situ in other areas. Based on the overall features in various areas of the oral cavity, the lesion was diagnosed as field cancerization.

Conclusion. Reviewing the literature revealed the presence of a field with genetically altered cells appear to be induced by tobacco (smoking/smokeless form). The large number of premalignant cells in the fields may increase cancer risk considerably. Thus screening and monitoring of the field may have serious implications for oral cancer prevention.

Key words: field cancerization, oral cancer, tobacco chewing, premalignant lesions

Received: August 5, 2013; Accepted with revision: December 10, 2013; Available online: January, 3, 2014

http://dx.doi.org/10.5507/bp.2013.092

${ }^{a}$ Department of Oral Pathology and Microbiology, Babu Banarasi Das College of Dental Sciences, Lucknow, India

${ }^{b}$ Department of Oral Medicine, Babu Banarasi Das College of Dental Sciences, Lucknow, India

'Department of Oral Pathology and Microbiology, Babu Banarasi Das College of Dental Sciences, Lucknow, India

Corresponding author:Deepika Shukla, e-mail:deepika_shukla06@yahoo.com

\section{INTRODUCTION}

An important physiological function of epithelia is its protective role by its frequent self-renewal process. It also inevitably gets exposed to environmental substances, including carcinogens, leading to abnormal proliferation creating a vast area of genetically altered cancer fields. Such hyperplastic epithelia could form the basis of neoplastic transformation leading to the formation of the most common types of cancers of the human body.

Patients with head and neck squamous cell carcinoma often present with widespread multiple premalignant lesions in the upper aerodigestive tract ${ }^{1}$. A potential mechanism for the development of multiple oral premalignant lesions is explained by the field cancerization theory which proposes that carcinogenic exposure can cause simultaneous genetic defects in the epithelium of the upper aerodigestive tract, putting the epithelium at high risk, for the development of multiple lesions².

Field cancerization is a well-known and well-documented process of malignant transformation first coined by Slaughter et al. in 1953 (ref. ${ }^{3}$ ). Since then the term field cancerization is applied to explicate the oral cancer developing in multifocal areas of a precancerous change, abnormal tissues surrounding the tumor, oral cancer often consisting of multiple independent lesions that may coalesce and the persistence of abnormal tissue even after surgery $^{4}$. Tobacco chewing was considered to be the major source of field cancerization of the oral cavity in the Indian population ${ }^{5}$. However certain carcinogens from tobacco chewing and tobacco smoking are identical, possibly the amount of exposure between these tobacco habits is different in the Indian population ${ }^{5}$.

Currently, absence of abnormal cells reviewed by histology biopsies often precludes the diagnosis of cancer ${ }^{6}$. Nevertheless, histologically normal biopsy specimen that possess molecular signatures of cancer fields suggest either the tumor was missed by the biopsy procedure, or that some cells in the tissue are progressing towards malignancy ${ }^{6}$. Such high-risk patients will require close surveillance for early detection of disease. Thus this review highlights all the risk factors associated with multiple oral premalignant lesions with a case report of extensive field cancerization in a female patient. The field cancerization will probably help clinicians in complementing evaluation of pathologic biopsy specimen.

\section{CASE REPORT}

A 63 year old female patient with a low socio economic status residing in a remote rural area and working on a daily wage, reported with the chief complaint of pain for one and half years and growth on the lips and 
in the oral cavity for three years (Fig. 1A). She visited a local doctor for the same problem for which she was prescribed with a topical application of candid- mouth paint, which relieved the pain for some time. She gave a history of tobacco chewing 5-6 times /day for 22 years and smoking 10-15 bidis a day for 15 years. On examination multiple brownish yellow papular proliferative growths were seen on the right upper and lower lip for 3 years measuring approximately $1 \times 1.5 \mathrm{~cm}, 0.5 \times 1 \mathrm{~cm}$ respectively, which were firm and non-tender (Fig. 1B). Upon intraoral examination generalized hyperkeratotic verruciform type white lesions involving right and left buccal mucosa, lower labial mucosa, upper and lower vestibule, dorsal, ventral and right lateral border of the tongue, hard and soft palate were evident. The lesion involving the hard $(5 \times 3 \mathrm{~cm})$ and soft palate $(3 \times 2 \mathrm{~cm})$ was verruco-papillary intermixed with erythematous areas, tender, with irregular surface (Fig. 2A). In the right buccal mucosa hyperkeratotic white lesion extended from commissure to retromolar area antero-posteriorly, upper to lower vestibule supero-inferiorly measuring $6 \times 4 \mathrm{~cm}$ with irregular surface, non-tender, non scrapable, with pebbly appearance (Fig. 2B). The dorsum and lateral border of the tongue showed a thick whitish, verruciform, non scrapable growth measuring about $3 \times 3$ $\mathrm{cm}$ and $3 \times 4 \mathrm{~cm}$ respectively (Fig. 2C and 2D). There was marked restriction in the movement of the tongue. On palpation there were three palpable, tender, mobile right submandibular lymph nodes. A provisional diagnosis of verrucous carcinoma of the lip, proliferative verrucous leukoplakia of oral mucosa and field cancerization was made. Routine blood investigations revealed that the patient was anaemic and positive for Monteux test. The postero-anterior view of the patient's chest radiograph revealed bilateral hyper-inflated lungs with pulmonary parenchymal calcification and cardiomegaly. The patient was referred to a general physician and following the additional investigations like sputum examination, aspiration from lymph nodes, and echocardiogram. The patient was diagnosed with pulmonary tuberculosis with cardiomegaly and advised on treatment. She was subjected to incisional biopsy of right buccal mucosa, hard palate, right labial mucosa, and lateral border of the tongue, under the physicians' supervision. The tissues were processed and stained with hematoxylin and eosin stain.

Section of the lesion on the upper lip mucosa of right commissural area revealed hyperparakeratinized stratified squamous epithelium with broad pushing rete ridges devoid of connective tissue. The surface parakeratin plugging with hyperplastic epithelial cells with occasional inflammatory cells suggested a diagnosis of verrucous carcinoma (Fig. 3A). Tissue from hard palate revealed invading islands and sheets of dysplastic epithelial cells showing features of nuclear hyperchromatism, abnormal mitotic figures, loss of cohesion, and altered nuclear cytoplasmic ratio with prominent keratin pearls in the connective tissue with mild inflammatory reaction from which the diagnosis of well/differentiated squamous cell carcinoma was made (Fig. 3B).

The hematoxylin and eosin stained sections from right lower labial mucosa revealed top to bottom dysplastic epi- thelium with features of loss of basal cell polarity, nuclear hyperchromatism, abnormal mitotic figures, and loss of cohesion with thin dropshaped rete ridges the features of which were suggestive of carcinoma in-situ (Fig. 3C). A diagnosis of severe dysplasia was made for the tissue from the lateral border of the tongue which showed hyperplastic parakeratinized stratified squamous epithelium with the dysplastic features extending to $2 / 3^{\text {rd }}$ of the epithelium with thin long rete ridges with minimal amount of papillary connective tissue (Fig. 3D). The overall features in various areas of the oral cavity led us to make a diagnosis of field cancerization. Because of extensive involvement of the oral cavity and her systemic illness, the patient was referred to a regional cancer center for further treatment.

\section{DISCUSSION}

Field cancerization is used to explain the existence of preneoplastic processes at multiple sites often with the hypothesis that these have developed independently. The multiple premalignant lesions in the entire oral cavity could result from exposure to carcinogens that can cause multiple genetic abnormalities in the whole tissue region. Another hypothesis for the development of multiple squamous cell lesions could be the pervasive migration of tumor cells through the whole aerodigestive tract either via saliva (micrometastasis) or via intraepithelial migration of the progeny of the initially transformed cells. An exogenous agent like tobacco is strongly associated with increase in the risk of multiple oral preneoplastic lesions and may be the major cause of field cancerization of the oral cavity in the Indian population. The risk of multiple oral premalignant lesions for lifetime chewers was reported as intermediate when compared to single lesions of leukoplakia, oral submucous fibrosis, and erythroplakia. The major carcinogens recognized in chewing tobacco, comprise tobacco-specific N-nitrosanes predominantly N-Nitrosononicotone and 4(Methyl nitrosamino)-1-(3pyridyl)-1-butanone ${ }^{7}$. Studies done in the Indian population have reported that tobacco smoking is a weak risk factor for multiple oral squamous cell lesions ${ }^{5}$. Possibly, smoking involves the inhaling of smoke, which may have less contact with the mouth and more contact with the throat and lungs than tobacco chewing. However some of the carcinogens from smoking and smokeless tobacco are the same, perhaps the amount of exposure between these tobacco practices is different in the Indian population. The association between alcohol drinking and multiple oral premalignant lesions was not evident.

Various authors have stated several oral field changes in tumor distant mucosa and tumor adjacent mucosa in OSCC patients associated with different risk factors.

\section{Morphological changes}

These include increase in nuclear size, discontinuous nuclear membrane, numerous Feulgen-negative areas, increased associated chromatin surrounding the clear areas, absence of a single large nucleolus, altered nuclear to cy- 


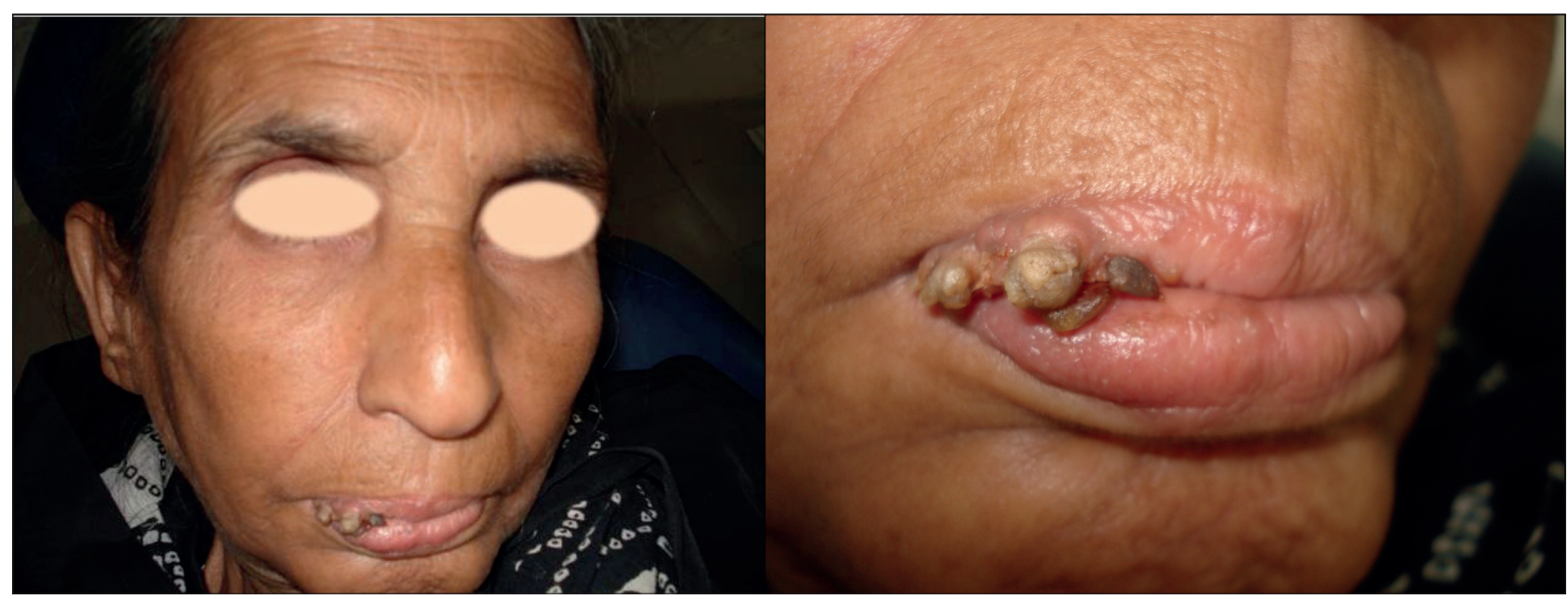

Fig. 1.

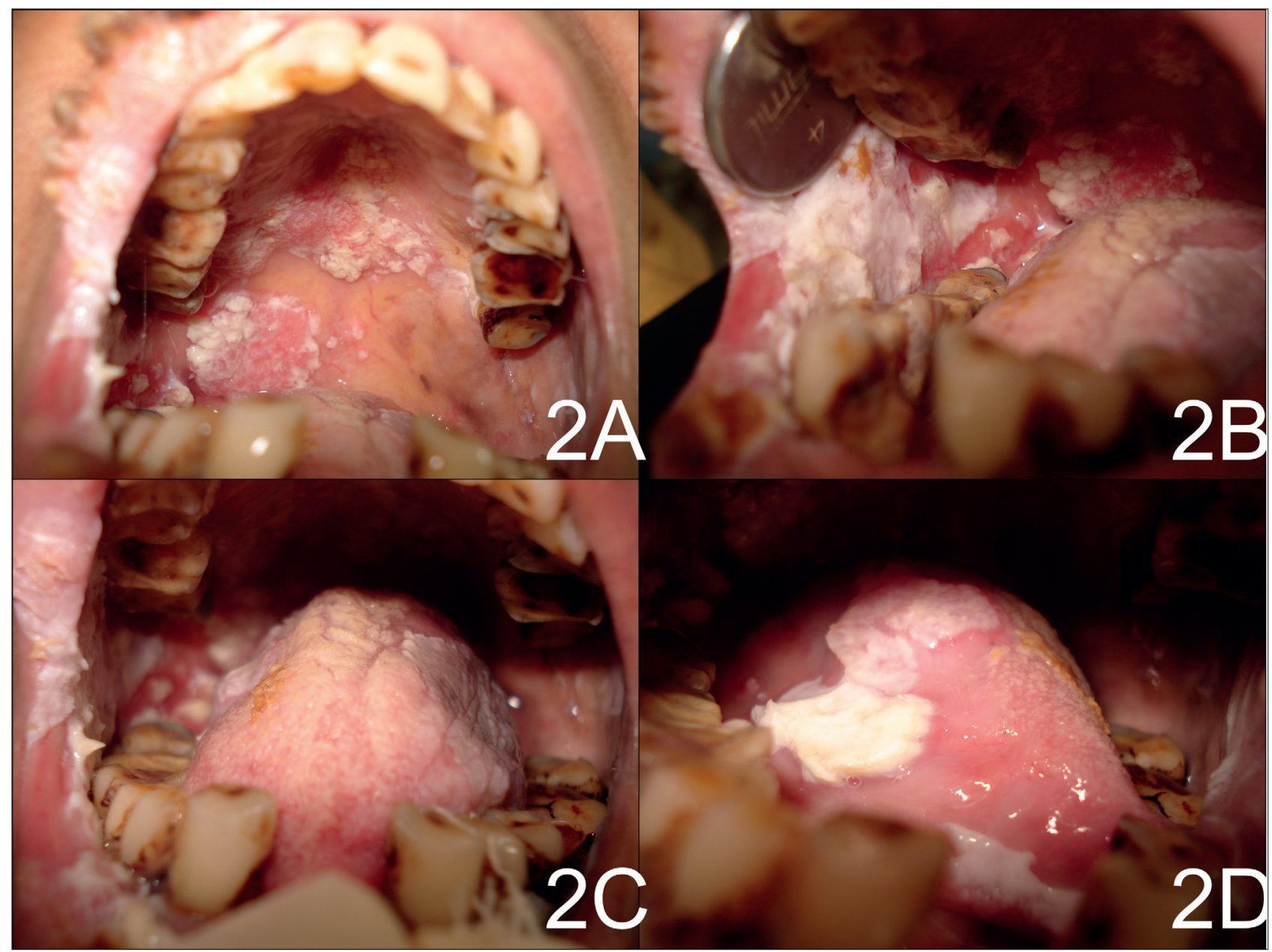

Fig. 2.

toplasmic area ratio and reduction in cytoplasmic area in the normal buccal mucosa of patients with SCC (ref. $\left.{ }^{8-11}\right)$.

\section{Molecular changes}

Studies have reported aneuploidy in hyperplastic/ inflammatory mucosa in tumor distant areas which later developed into an invasive carcinoma ${ }^{12}$.

\section{Chromosomal aberrations:}

Various chromosomal aberrations were seen in the normal mucosa opposite the side of OSCC (ref. ${ }^{13}$ ). Polysomies of chromosomes 7 and 17 and a significant loss of chromosome $\mathrm{Y}$ was observed in tumor adjacent mucosa from OSCC patients with a history of smoking 


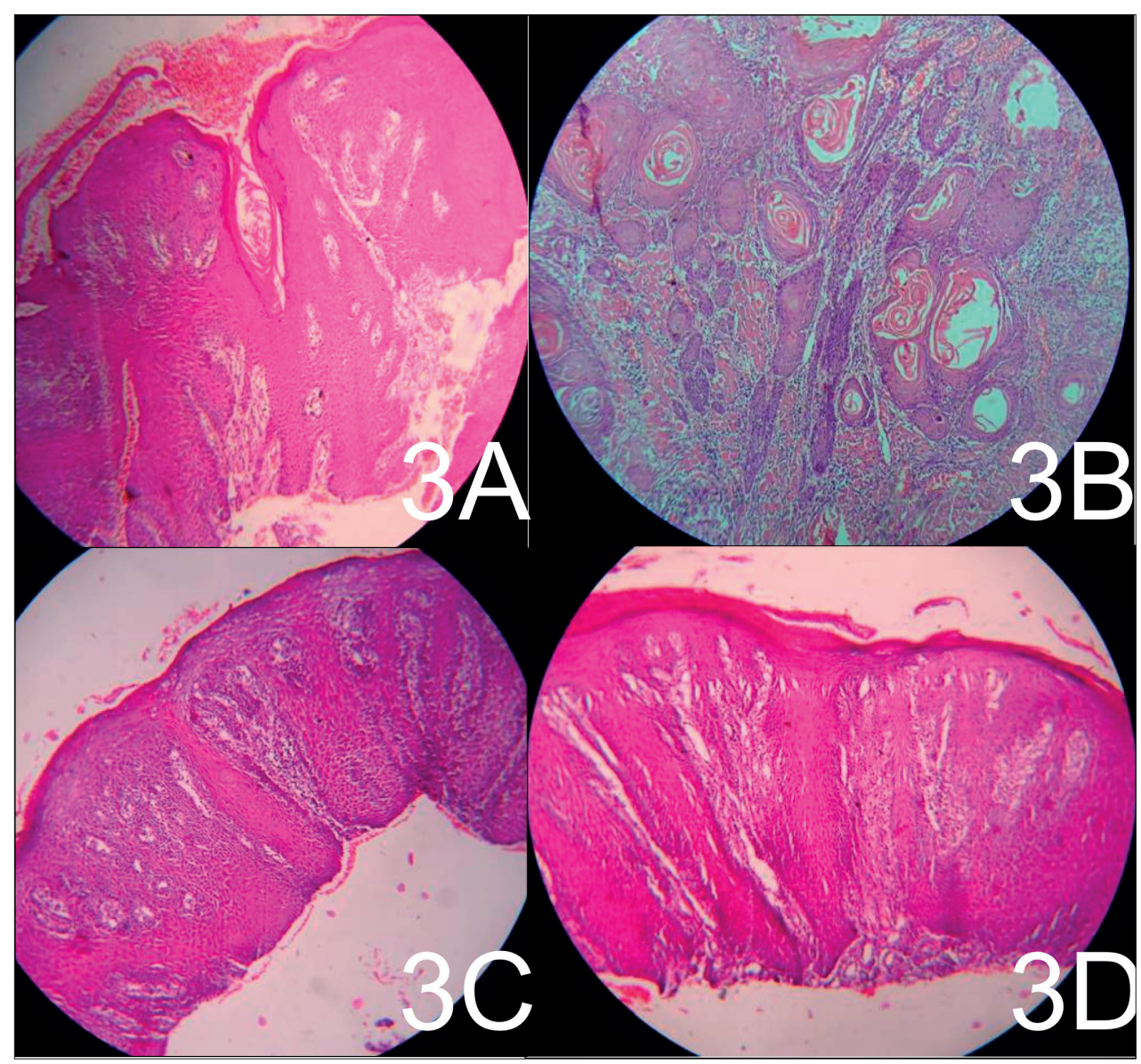

Fig. 3.

but this loss appeared not to be present in nonsmoking patients $^{14-16}$.

Cytokeratins: Aberrant expression of cytokeratins was observed in the mucosa of patients during development of OSCC ( ref. $^{17,18}$ ). Normal mucosa from OSCC patients showed the presence of cytokeratin $7,8,13,16$, and 19 at abnormal intraepithelial sites or at abnormal intraepithelial levels ${ }^{19-22}$.

Abnormality with cell cycle regulation: Overexpression of the proto-oncogene cyclin D1 has been reported in about half of the OSCC ( ref. $^{23}$ ). The amplification frequency of Cyclin D1 progresses from premalignant lesions to invasive carcinoma ${ }^{23}$. Cyclin D1 expression was observed in sections of normal mucosa adjacent to OSCC and was absent in sections from healthy individuals ${ }^{24}$.

The proto-oncogene product eIF4E or mRNA 5' capbinding protein plays a key role in the regulation of translation in cell growth and proliferation ${ }^{25}$. OSCC patients and histologically normal margins of resected OSCC show increased expression of this protein ${ }^{26}$.

Growth factors: Epidermal growth factor mRNA overexpression as well as protein overexpression, which indicates proliferation, has been demonstrated in nearly all OSCC (ref. ${ }^{27-29}$ ). Epidermal growth factor receptor expression increases during the progression of normal epithelium to dysplasia to carcinoma ${ }^{30}$. Several authors have reported increased expression of Epidermal growth factor receptor, Transforming growth factor- $\alpha$ mRNA lev- els and proteins in normal tumor adjacent mucosa (TAM) of OSCC patients ${ }^{27-31}$.

Increased proliferation: Furthermore TAM from OSCC patients showed an increased number of proliferating epithelial cells ${ }^{32}$, loss of function of the tumor suppressor p53 (ref. ${ }^{33}$ ), focal p53 positivity ${ }^{3436}$ and mutations in the $p 53$ gene $^{34,37}$ which can lead to uncontrolled cell division and progressive genomic instability. Literature reveals that frequency of p53 positive cells gradually increases as oral epithelium progresses from normal to hyperplasia to dysplasia to carcinoma ${ }^{36,38}$.

Inhibition of apoptosis: Additionally, studies have reported absence of bcl-2 (an apoptosis inhibitor) expression in oral cancer and in normal tumor adjacent mucosa compared to control group.

Genetic polymorphism of drug metabolizing enzymes: Besides the expression of glutathione $S$-transferase isoenzymes which are detoxification enzymes were significantly higher in the normal oral mucosa from OSCC patients who later developed a second primary tumor than in normal oral mucosa from OSCC patients who stayed free of disease for at least 7 years $^{39}$.

Numerous studies have performed molecular analyses on tumor-adjacent "normal tissue" and surgical margins to assess the presence of a field lesion using markers for loss of heterozygosity, microsatellite alterations ${ }^{40}$, chromosomal instability ${ }^{41}$, and mutations in the TP53 gene ${ }^{42}$. These studies reported that one-third of unselected tumors 
of OSCC have tumor-associated genetic alterations in a biopsy taken from the macroscopically normal TAM.

Studies have also reported that tobacco smoking is a risk factor for pulmonary tuberculosis as seen in the present case, with a dose-response relationship with the number of cigarettes consumed daily ${ }^{43,44}$. This could be attributed to nicotine that turns off the production of Tumor necrosis factor- $\alpha$ by the macrophages in the lungs, making the patient more susceptible to the tuberculosis infection. Molecular and histopathologic alterations identified in the bronchial epithelium of tobacco smokers suggest that smoking exerts field cancerization effects on bronchial epithelium increasing the risk for the subsequent development of lung cancer ${ }^{45,46}$.

Further research is required to detect the fields carrying the high risk for cancer. Besides host factors, like tobacco consumption, the biological characteristics of the field also plays a important role in OSCC development. Clinical trials should be performed to identify approximately where the lesion will develop and to monitor the disease process. Moreover, knowledge of the tumor associated genetic alterations that precede the development to cancer will provide a basis for a rational therapy of the premalignant lesions.

\section{CONCLUSION}

The presence of a field with genetically altered cells appear to be induced by tobacco (smoking/smokeless form), which indicates field cancerization induced by carcinogens rather than due to migration of transformed cells. The large number of premalignant cells in the fields possibly can increase cancer risk considerably. This also clarifies the high incidence of secondary cancers in posttreated oral cancer patients. Thus screening and monitoring of the field may have serious implications for oral cancer prevention.

\section{ACKNOWLEDGEMENT}

Author contributions: All autors contributed equally to preparing the manuscript.

Conflict of interest statement: The authors state that there are no conflicts of interest regarding the publication of this article.

\section{REFERENCES}

1. Chung KY, Mukhopadhyay T, Kim J, Casson A, Ro JY, Goepfert H, Hong WK, Roth JA. Discordant p53 Gene Mutations in Primary Head and Neck Cancers and Corresponding Second Primary Cancers of the Upper Aerodigestive Tract. Cancer Res 1993;53:1676-83.

2. Califano J, Riet $P$ van der, Westra W, Nawroz H, Clayman G, Piantadosi S, Corio R, Lee D, Greenberg B, Koch W, Sidransky D. Genetic Progression Model for Head and Neck Cancer: Implications for Field Cancerization. Cancer Res 1996;56:2488-92.

3. Slaughter DP, Southwick HW, Smejkal W. "Field cancerization" in ora stratified squamous epithelium. Clinical implications of multicentric origin. Cancer 1953;6:963-8.
4. Braakhuis BJM, Tabor MP, René Leemans C, van der Waal I, Snow GB, Brakenhoff $\mathrm{RH}$. Second primary tumors and field cancerization in oral and oropharyngeal cancer: Molecular techniques provide new insights and definitions. Head Neck 2002;24:198-206.

5. Thomas G, Hashibe M, Jacob BJ, Ramadas K, Mathew B, Sankaranarayanan R, Zhang Z-F. Risk factors for multiple oral premalignant lesions. Int J Cancer 2003;107:285-91.

6. Dakubo GD, Jakupciak JP, Birch-Machin MA, Parr RL. Clinical implications and utility of field cancerization. Cancer Cell Int 2007;7:2.

7. Hoffmann D, Djordjevic MV. Chemical composition and carcinogenicity of smokeless tobacco. Adv Dent Res 1997;11:322-9.

8. Nieburgs $\mathrm{HE}$, Herman $\mathrm{BE}$, Reisman $\mathrm{H}$. Buccal cell changes in patients with malignant tumours. Lab Invest 1962;11:80.

9. Ogden GR, Cowpe JG, Green MW. The effect of distant malignancy upon quantitative cytologic assessment of normal oral mucosa. Cancer 1990;65:477-80.

10. Ogden GR, Cowpe JG, Green MW. Detection of field change in oral cancer using oral exfoliative cytologic study. Cancer 1991;68:1611-5.

11. Incze J, Vaughan CW Jr, Lui P, Strong MS, Kulapaditharom B. Premalignant changes in normal appearing epithelium in patients with squamous cell carcinoma of the upper aerodigestive tract. Am J Surg 1982;144:401-5.

12. Högmo A, Lindskog S, Lindholm J, Kuylenstierna R, Auer G, MunckWikland E. Preneoplastic oral lesions: the clinical value of image cytometry DNA analysis, p53 and p21/WAF1 expression. Anticancer Res 1998;18:3645-50.

13. Ai H, Barrera JE, Pan Z, Meyers AD, Varella-Garcia M. Identification of individuals at high risk for head and neck carcinogenesis using chromosome aneuploidy detected by fluorescence in situ hybridization. Mutat Res 1999;439:223-32.

14. Voravud N, Shin DM, Ro JY, Lee JS, Hong WK, Hittelman WN. Increased polysomies of chromosomes 7 and 17 during head and neck multistage tumorigenesis. Cancer Res 1993;53:2874-83.

15. Choi G, Chung K. Polysomies of chromosomes 7 and 17 in head and neck squamous cell carcinomas. Arch Otolaryngol Head Neck Surg 1996;122:1062-7.

16. Oijen M. G. C. T. V, Poorts LK, Slootweg PJ. Mucosal changes in head and neck cancer. Incipient tumors or micrometastases? J Cancer Res, ClinOncol 1999;125:S105.

17. Van der Velden LA, Schaafsma HE, Manni JJ, Ramaekers FC, Kuijpers W. Cytokeratin expression in normal and (pre)malignant head and neck epithelia: an overview. Head Neck 1993;15:133-46.

18. Lindberg K, Rheinwald JG. Suprabasal 40 kd keratin (K19) expression as an immunohistologic marker of premalignancy in oral epithelium. Am J Pathol 1989;134:89.

19. Copper MP, Braakhuis BJ, de Vries N, van Dongen GA, Nauta JJ, Snow GB. A panel of biomarkers of carcinogenesis of the upper aerodigestive tract as potential intermediate endpoints in chemoprevention trials. Cancer 1993;71:825-30.

20. Ogden GR, Lane EB, Hopwood DV, Chisholm DM. Evidence for field change in oral cancer based on cytokeratin expression. $\mathrm{Br} J$ Cancer 1993;67:1324-30.

21. Bongers V, Snow GB, de Vries N, Braakhuis BJ. Potential early markers of carcinogenesis in the mucosa of the head and neck using exfoliative cytology. J Pathol 1996;178:284-9.

22. Bosch FX, Ouhayoun JP, Bader BL, Collin C, Grund C, Lee I, Franke WW. Extensive changes in cytokeratin expression patterns in pathologically affected human gingiva. Virchows Arch B Cell Pathol Incl Mol Pathol 1989;58:59-77.

23. Izzo JG, Papadimitrakopoulou VA, Li XQ, Ibarguen H, Lee JS, Ro JY, El-Naggar A, Hong WK, Hittelman WN. Dysregulated cyclin D1 expression early in head and neck tumorigenesis: in vivo evidence for an association with subsequent gene amplification. Oncogene 1998;17:2313-22.

24. Bartkova J, Lukas J, Müller H, Strauss M, Gusterson B, Bartek J. Abnormal Patterns of D-Type Cyclin Expression and G1 Regulation in Human Head and Neck Cancer. Cancer Res 1995;55:949-56.

25. Sonenberg N, Gingras AC. The mRNA 5' cap-binding protein elF4E and control of cell growth. Curr Opin Cell Biol 1998;10:268-75.

26. Franklin S, Pho T, Abreo FW, Nassar R, De Benedetti A, Stucker FJ, Nathan CA. Detection of the proto-oncogene elF4E in larynx and hypopharynx cancers. Arch Otolaryngol Head Neck Surg 1999;125:17782.

27. Eisbruch A, Blick M, Lee JS, Sacks PG, Gutterman J. Analysis of the 
Epidermal Growth Factor Receptor Gene in Fresh Human Head and Neck Tumors. Cancer Res 1987;47:3603-5.

28. Grandis JR, Tweardy DJ. Elevated Levels of Transforming Growth Factor a and Epidermal Growth Factor Receptor Messenger RNA Are Early Markers of Carcinogenesis in Head and Neck Cancer. Cancer Res 1993;53:3579-84.

29. Christensen ME, Engbaek F, Therkildsen MH, Bretlau P, Nexø E. A sensitive enzyme-linked immunosorbent assay used for quantitation of epidermal growth factor receptor protein in head and neck carcinomas: evaluation, interpretations and limitations. $\mathrm{Br} \mathrm{J}$ Cancer 1995;72:1487-93.

30. Shin DM, Ro JY, Hong WK, Hittelman WN. Dysregulation of Epidermal Growth Factor Receptor Expression in Premalignant Lesions during Head and Neck Tumorigenesis. Cancer Res 1994;54:3153-9.

31. Van Oijen MG, Rijksen G, ten Broek FW, Slootweg PJ. Increased expression of epidermal growth factor receptor in normal epithelium adjacent to head and neck carcinomas independent of tobacco and alcohol abuse. Oral Dis 1998;4:4-8.

32. Schwint AE, Savino TM, Lanfranchi HE, Marschoff E, Cabrini RL, Itoiz ME. Nucleolar organizer regions in lining epithelium adjacent to squamous cell carcinoma of human oral mucosa. Cancer 1994;73:2674-9.

33. Kirsch DG, Kastan MB. Tumor-suppressor p53: implications for tumor development and prognosis. J Clin Oncol 1998;16:3158-68.

34. Nees M, Homann N, Discher H, Andl T, Enders C, Herold-Mende C, Schuhmann A, Bosch FX. Expression of Mutated p53 Occurs in Tumor-distant Epithelia of Head and Neck Cancer Patients: A Possible Molecular Basis for the Development of Multiple Tumors. Cancer Res 1993;53:4189-96.

35. Cruz IB, Snijders PJ, Meijer CJ, Braakhuis BJ, Snow GB, Walboomers $J M$, van der Waal I. p53 expression above the basal cell layer in oral mucosa is an early event of malignant transformation and has predictive value for developing oral squamous cell carcinoma. J Pathol 1998;184:360-8.

36. Shin DM, Kim J, Ro JY, Hittelman J, Roth JA, Hong WK, Hittelman WN Activation of p53 Gene Expression in Premalignant Lesions during Head and Neck Tumorigenesis. Cancer Res 1994;54:321-6.
37. Waridel F, Estreicher A, Bron L, Flaman JM, Fontolliet C, Monnier $P$, Frebourg T, Iggo R. Field cancerisation and polyclonal p53 mutation in the upper aero-digestive tract. Oncogene 1997;14:163-9.

38. el-Naggar AK, Lai S, Luna MA, Zhou XD, Weber RS, Goepfert H, Batsakis JG. Sequential p53 mutation analysis of pre-invasive and invasive head and neck squamous carcinoma. Int J Cancer J Int Cancer 1995;64:196-201.

39. Bongers V, Snow GB, de Vries N, Cattan AR, Hall AG, van der Waal I, Braakhuis BJ. Second primary head and neck squamous cell carcinoma predicted by the glutathione S-transferase expression in healthy tissue in the direct vicinity of the first tumor. Lab Investig J Tech Methods Pathol 1995;73:503-10.

40. Tabor MP, Brakenhoff RH, Houten VMM van, Kummer JA, Snel MHJ, Snijders PJF, Snow GB, Leemans CR, Braakhuis BJM. Persistence of Genetically Altered Fields in Head and Neck Cancer Patients Biological and Clinical Implications. Clin Cancer Res 2001;7:1523-32.

41. Hittelman WN. Genetic instability in epithelial tissues at risk for cancer. Ann NY Acad Sci 2001;952:1-12.

42. Brennan JA, Mao L, Hruban RH, Boyle JO, Eby YJ, Koch WM, Goodman $\mathrm{SN}$, Sidransky D. Molecular assessment of histopathological staging in squamous-cell carcinoma of the head and neck. N Engl J Med 1995;332:429-35.

43. Davies PDO, Yew WW, Ganguly D, Davidow AL, Reichman LB, Dheda K, Rook GA. Smoking and tuberculosis: the epidemiological association and immunopathogenesis. Trans R Soc Trop Med Hyg 2006;100:291-8.

44. Alcaide J, Altet MN, Plans P, Parrón I, Folguera L, Saltó E, Dominguez A, Pardell H, Salleras L. Cigarette smoking as a risk factor for tuberculosis in young adults: A casecontrol study. Tuber Lung Dis 1996;77:112-6.

45. Mao L, Lee JS, Kurie JM, Fan YH, Lippman SM, Broxson A, Khuri FR, Hong WK, Lee JJ, Yu R, Ro JY, Kemp BL, Morice RC, Walsh GL, Hittelman WN. Clonal Genetic Alterations in the Lungs of Current and Former Smokers. J Natl Cancer Inst 1997;89:857-62.

46. Wistuba II, Lam S, Behrens C, Virmani AK, Fong KM, LeRiche J, Samet JM, Srivastava S, Minna JD, Gazdar AF. Molecular damage in the bronchial epithelium of current and former smokers. J Natl Cancer Inst 1997;89:1366-73. 